\title{
GENERALIZED CYTOMEGALOVIRUS INFECTION IN A GORILLA*
}

Cytomegaloviruses (CMV), alternatively referred to as salivary gland or cytomegalic inclusion disease viruses in the earlier literature, are a group of highly species-specific agents infecting various species of nammals. Cytomegaly and prominent nuclear inclusion formation in the affected cells are pathognomonic features of the infection of the viruses. Although CMV manifest a low degree of pathogenicity in the hosts, generalized infection may end fatally (Welley, 1965). In subhuman primates, the pathological evidence of CMV infection has been reported in Cebus fatuelles (Cowdry and Scott, 1935a), rhesus monkeys (Cowdry and Scott, 1935b) and chimpanzees (Vogel and Pinkerton, 1955). CMV strains have been isolated from African green monkey kidney cell cultures (Black, Hartley and Rowe, 1963 ; Malherbe and Harwin, 1963). Recently, a new herpesvirus with properties similar to those of CMV was also isolated from squirrel monkey kidney cell cultures (Meléndez et al., 1968). In the gorilla, however, CMV infection has not been reported. This communication describes histopathological findings in a gorilla in which the characteristic features of CMV infection were observed.

The animal was a 3-year old lowland gorilla, Gorilla gorilla gorilla, which had been kept at Hirakata Park, Hirakata City, Osaka, for one and a half years. The animal was found ill on August 28, 1961. Clinically, intermittent bloody diarrhea, anorexia, anemia, abdominal pain, dehydration and emaciation were observed. The symptoms changed in the balance for 38 days and the animal was dead on October 5, 1961. The animal did not respond to antibiotic, chemotherapeutic or symptomatic treatments. Repeated attempts to isolate Shigella organisms from the feces during the coruse of illness failed.

The main pathological findings were severe colitis with ulceration, focal interstitial pneumonia, toxic nephrosis, atrophy and sclerosis of the spleen and worm nodule formation in the colon caused by Oesophagostomum stephanostomum as identified by Katae, Terauchi and Yamada (1962). Markedly hypertrophied cells with eosinophilic nuclear inclusions were frequently found in the alveolar walls and lumen of the lungs, the red pulp of the spleen, the parenchymal cells of the liver and the interstitium of the kidneys. Only one inclusion-bearing cell was found in one of several preparations taken from the submaxillary glands. The inclusionbearing cells (Fig. 1) measured up to $30 \mu$ in diameter and the inclusion stained positive with Feulgen reagents. Little cellular infiltration or necrosis was observed in the affected organs except in the lungs in which interstitial pneumonia was found. Multinucleated giant cells were not observed in the affected sites.

The severe colitis with ulcers may be the cause of the general conditions of the animal. The ulcers reached the submucosae and showed the features of bacillary dysentery. It seems unlikely, however, that dysentery bacilli caused the

* Request for reprints should be addressed to Dr. Otoshiro Isshiki, 6-919 Hamaderamotomachi, Sakai City, Osaka. 


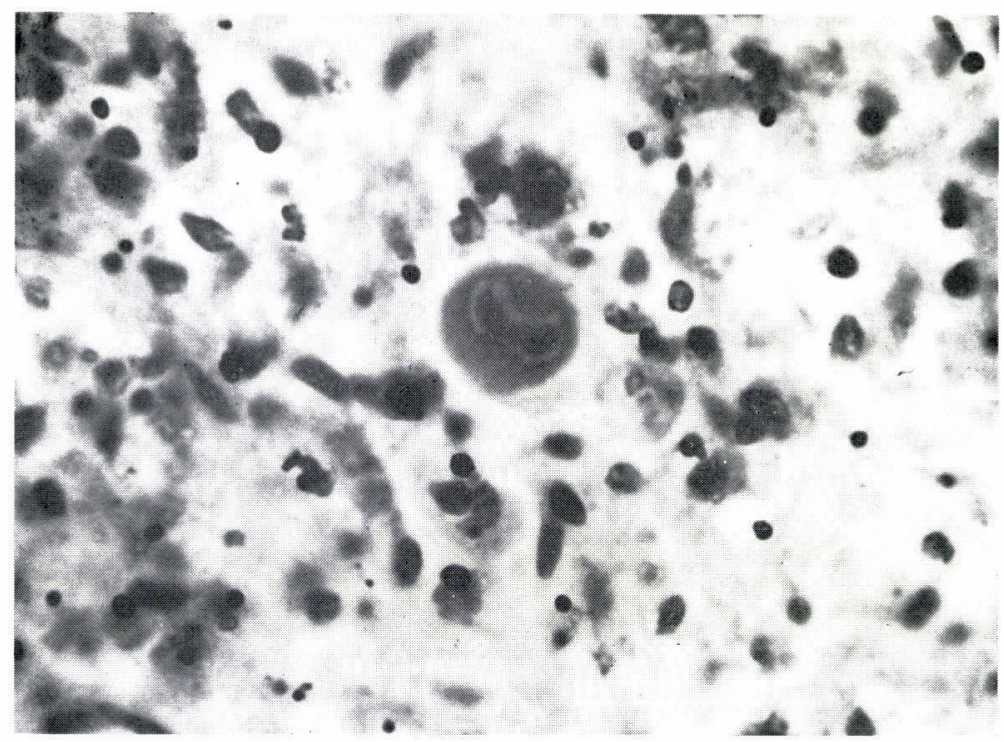

Fig. 1. Spleen of the gorilla. A greatly hypertrophied inclusionbearing cell is seen. Hematoxylin and eosin.

colitis, since Shigella organisms could not be isolated from the feces nor did the animal respond to antibiotic and chemotherapeutic treatments. No protozoan parasites were found in and around the ulcers. The ulcers were clearly distinct from the worm nodules which were encapsulated and infiltrated with eosinophils. Inclusions were not found in the ulcers. Thus, the cause of the colitis remains unclear. Colitis with ulcers was also observed in 3 of 14 human adult autopsy cases of CMV infection reported by Wong and Warner (1962).

The characteristic morphology of highly hypertrophied cells with Feulgen positive nuclear inclusions, a rather mild cellular response in the affected organs and the lack of tendency to form multinucleated giant cells suggest that the causative agent in this case may be CMV being clearly distinct from other viral agents such as B virus. Inclusions induced by CMV are located predominently in the vascular endothelium and macrophages in generalized human adult cases, while those in infants are located primarily in the epithelial cells (Wong and Warner, 1962). In this respect, the present case resembled human adult cases. Virological and serological examinations on the animal was not performed.

\section{REFERENCES}

Black, P. H., Hartley, J. W. And Rowe, W. P. (1963): Isolation of a cytomegalovirus from African green monkey. Proc. Soc. Exp. Biol. Med. 112, 601-605.

COWDry, E. V. AND ScOTT, G. H. (1935a): Nuclear inclusions suggestive of virus action in salivary glands of the monkey, Cebus fatuelles. Am. J. Pathol. 11, 647-658.

Cowdry, E. V. AND ScotT, G. H. (1935b): Nuclear inclusions in the kidneys of Macacus rhesus monkeys. Am. J. Pathol. 11, 659-668.

Katae, H., Terauchi, J. And YamadA, H. (1962): Oesophagostomiasis in the gorilla. Report of two cases. The 18th Meeting of the Western Branch of the Society of Japanese 
Parasitologists. Nara City.

Malherbe, H. AND HARwin, R. (1963): Cytopathic effects of vervet monkey viruses. South African Med. J. 37, 407-411.

Meléndez, L. V., Daniel, M. D., Hunt, R. D. And García, F. G. (1968): An apparently new hepesvirus from primary kidney cultures of the squirrel monkey (Saimiri sciureus). Lab. Animal Care 18, 374-381.

Vogel, F. S. AND Pinkerton, H. (1955): Spontaneous salivary gland virus disease in chimpanzees. Arch. Pathol. 60, 281-285.

WelleR, T. H. (1965): Cytomegaloviruses. In Viral and Rickettsial Infections of Man. 4th ed. 926-931. (Horsfall, F. L. and Tamm, I., eds.).

WONG, T.-W. AND WARNER, N. E. (1962): Cytomegalic inclusion disease in adults. Report of 14 cases with review of literature. Arch. Path. 403-422.

Department of Animal Pathology,

School of Veterinary Medicine,

University of Osaka Prefecture,

YOSHIKI TSUCHIYA*

Sakai City, Osaka 591, Japan

Veterinary Station, Hirakata Park,

Sakai City, Osaka, Japan

OTOSHIRO ISSHIKI**

HIROSHI YAMADA

Received: October 11th, 1969

* Present address: Department of Enteroviruses, National Institute of Health, Nakato, Murayama-machi, Kitatama-gun, Tokyo 190-12, Japan

** Present address: Department of Biology, Kobe Gakuin University, Kobe City, Hyogo 655, Japan

土屋嘉樹 - 一色於蒐四郎 (大阪府堺市大阪府立大学家畜病理学教室)

山田宏 (大阪府枚方市 枚方パーク) 